\title{
Theatrical Traces of the Past in the Contemporary Theatre: The Case of Simos Kakalas
}

\author{
Tania Neofytou \\ Department of Theatre Studies, Open University of Cyprus, Nicosia, Cyprus
}

\begin{abstract}
This paper examines the contemporary theatre of Simos Kakalas, the director of Horos Theatre Company, and his troupe. The object of this study is the performances of the troupe during the period 2004-2016, which include: (1) the eight different versions of the dramatic idyll Golfo, written in 1894 by Spyridon Peresiadis; (2) the three different versions of the tragedy Erofili, written in Crete in 1595 by Georgios Hortatzis, and (3) the three different versions of the ancient Greek tragedy Euripides' Orestes written in 408 B.C. The research shows how these performances bring the young audience closer to the Greek theatre, tradition and identity, and at the same time they lead the audience's thought to current issues. It also explores how Kakalas brings the past closer to us to the present time, combining the poetic fifteen-syllable verse, the theatrical codes of the Greek "bouloukia" (the wandering troupes who used to play at squares in the nineteenth century), the technique of narration, parody and shadow theatre with postmodern style, manga masks, video projections and anime.
\end{abstract}

Keywords: Simos Kakalas, Contemporary Greek Theatre, Orestes, Erofili, Golfo

\section{Introduction}

From 2004 till today, Simos Kakalas and Horos Theatre Company bring to the fore Greek plays of the 19th century, the Cretan Renaissance and the classical Antiquity and utilize Greek theatrical tradition but also experiment with new forms. Specifically, during the period 2004-2014, the troupe presents eight different versions of the five act play Golfo. The play is a dramatic idyll, a kind of popular theatre, which presents the bucolic life in the country (Hatzipantazis, 2010, pp. 146-147; Puchner, 2006, pp. 339-361), written in 1894 by Spyridon Peresiadis, which has been identified with the Greek tradition and is considered to be one of the most popular plays of the Greek theatre (Katsioti, 2002; Vasiliou, 2004, pp. 122-124). All versions of the performance tour extensively in Greece, Bulgaria, Poland and Georgia (Konstantinakou, 2013; Neofytou, 2015). During 2008-2012, the troupe presents three different versions of the Renaissance tragedy Erofili, written by Georgios Hortatzis, around 1600, according to the researchers (Puchner, 1991, p. 129); a tragedy which is the most often-played tragedy of the Cretan theatre (Markaki, 2015; Puchner, 1991). The first version of Erofili (2008) tours in the villages of Crete. The second one is presented in 2010 in the Small Ancient Theatre of Epidaurus. The last version Erofili Synopsis (2012) is presented at the Athens Festival and then tours in Greece. From 2015 till

Tania Neofytou, B.A., Mphil, Ph.D. in Theatre Studies, Faculty of Theatre Studies, School of Philosophy, University of Athens (Greece), Adjunct Lecturer, Department of Theatre Studies, Open University of Cyprus (Cyprus). 
today, the troupe has presented three different versions of the ancient Greek tragedy Euripides' Orestes written in 408 B.C., the time of crisis in the Athenian Democracy (Hall, 1993) and has been placed among the dramas of the classical antiquity. The first version Orestes (February-March 2015) is presented in Avlaia Theatre in Thessaloniki. The second version (28-29 August 2015) is presented in the Ancient Theatre of Epidaurus and the third one (March-April 2016) is presented in Horos Theatre in Athens.

Kakalas and his theatre group present their performances in many versions. The director explains (Kakalas, 2015a) that they need to present new versions of the play, because they have many different thoughts about it, any time they retrace it. Kakalas chooses these "classic" plays in order to explore Greek identity and tradition, as the Greek directors Fotos Politis, Karolos Koun and Spyros Evaggelatos had done likewise, in the past. Kakalas points out (2010): "I cannot realize the present if I do not know where I come from. In theatre, it is not enough to read the classic plays, but we should rediscover our relation with them".

However, Kakalas destroys prejudice between Greek and foreign or literary and traditional. His performances try to bring the audience closer to the Greek theatrical tradition and identity, when at the same time they use post-modern techniques, experiment with new forms and direct the audience's thought to current issues. As Kakalas notes (2010): "tradition is what is passed on to you, but not to put it as a decoration on the wall". Below, we will examine how the director combines the poetic fifteen-syllable verse, the theatrical codes of the Greek "bouloukia" (the wandering troupes who used to play at squares in the nineteenth century), the technique of narration, parody and shadow theatre with manga masks, post-dramatic theatre, video projections and anime.

\section{Metrical Poetry}

All of these above mentioned plays are written in metrical poetry. After the Middle Ages, the meter characterizes the Greek poetry as far as the Greek literature is concerned. Kakalas chooses to keep the meter in two of these plays. In all versions of Golfo and Erofili, the fifteen-syllable (not rhyming at the first and rhyming at the second) verse remains. The director tries to convey the language of the past, proving this way that the fifteen-syllable verse remains alive and can communicate with the present (Kakalas, 2015b).

On the contrary, in Orestes, the director not only does he use prose, but he also chooses Yannis Tsarouchis', the great Greek painter's, translation, which is full of political hints, humor, irony and above all is not at all archaic, as Tsarouchis mentions occasionally (Tsarouchis, 1989a, pp. 51-53; 1989b, pp. 28, 56; 1990, pp. 96-99, 134). Due to this choice, Kakalas rejects archaism and shows that there is no Greek tradition coming from the 5th century B.C. (Kakalas, 2015b). He also tries to make the tragedy stay alive to the present, bringing back to it the popularity it used to have in antiquity (Kakalas, 2015b).

\section{The Use of the Mask}

Another characteristic in Kakalas' performances is the use of the mask. For Kakalas, the masks have

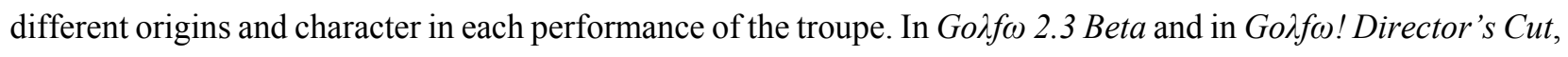
the characters wear extremely expressive masks inspired by the Japanese manga comics (Gravett, 2004). The masks turn the characters of the bucolic drama into modern comic heroes disengaging the play from the past. Simultaneously the manga masks contribute to modern reductions and reflect the T.V. dominance in the modern world. 
In Erofili Synopsis the masks play a key role in the atmosphere of mystery and the otherworldly character of the performance. The transformation of the actors into persons of the Renaissance Cretan tragedy contributes to distantiate acting and a similar use of the body and voice, in order to present the characters through exaggeration. We should not forget to mention the beginning of the play, at which the actress Helena Mavridou, acting the role of Haros (Death), is turned with her back naked towards the audience, wearing in the back of her head a mask referred to a bird-mask of the Italian Renaissance.

In Orestes, the masks create a mythological and ritual atmosphere, which is connected with the history of ancient drama and the use of the mask. The masks are affected by the Japanese Kabuki theatre and attribute the traits of the characters in detail. The members of Chorus are differentiated by wearing archaic masks having elements taken from the Cycladic figurines and Minoan frescoes. In Chorus' parodos the director tries to parody the stereotypic opinion of the modern spectator about how is an "authentic" presentation of ancient Greek drama: the Chorus wears the Roman high-heeled shoes called "kothornoi" (Taplin, 2007); the music is the "melos" of what is considered to be the first "stasimon" of Euripides' Orestes.

\section{The Technique of Narration}

In Kakalas' performances the troupe uses the technique of narration, which comes from the popular theatre. In

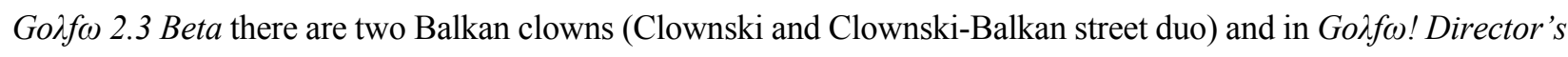
$\mathrm{Cut}$ there is a compère, who is a reference to the compère of "bouloukia", who makes the prologue of the performance. The word "boulouki" means a group of people, but in Greek theatre the word is used to characterize the wandering troupes who used to play at squares in the nineteenth century. The compère interferes into the action of the play, breaking the illusion, using the technique of narration, commenting and criticizing both the characters of the play and the Modern Greek and European culture and theatre (e.g. he parallelizes the performance with Ariane Mnouchkine's theatre). Patsalidis notes (2004) that the narrator is like a "post-Brecht" commentator who parodies and criticizes the clichés of the bucolic drama as it makes the researchers frequently argue about its Greek identity.

In the first two versions of Erofili, the troupe uses the technique of narration as a reference and as a connection with the long oral tradition of the folk poetry of the Greek and especially of the Cretan world (Alexiou, 1991, pp. 246-250; Beaton, 1980, pp. 36-38; Gemert, 1991, pp. 75-79). In the second version, the troupe organizes a traditional Cretan feast with live music, at which the actors sit in a circle, on rugs extended to the stage, and get up to narrate some scenes of the play, while music-intermedia interfere among the acts. Kakalas removes everything from the stage and gives emphasis to the narration. As Ioannides notes (2010), the performance brings to mind Peter Brook's emphasis on story-telling and the empty space and Anatoly Vasiliev's method regarding the coordination of speech and movement. In Erofili Synopsis, the actors create the framework of the theatrical convention to narrate Hortatzis' play, using a table as a stage, which recalls that stage the bouloukia set up temporarily to play their performances.

In Orestes, it is Apollo who plays the first part of the prologue, not Electra as it is written by Euripides. The director's intention is clear: the plot of the play is based on a game that God sets up. He is the one who narrates the story. The divine will and intervention is the master of the game, as it is proved at the end of the play, at which Apollo appears on a stool, as deus ex machina, and gives the solution, being a master of the scenic play (Goward, 2004, pp. 125-126; Mastronarde, 2010, pp. 107-110, 180-181, 185-187; Wohl, 2015, p. 20). 
The actors of Horos often use the Brechtian "estrangement effect" (Verfremdungseffekt) in their performances; in Golfo, Erofili Synopsis and Orestes the changing of roles through a simple changing of masks, the frozen images, the unnatural acting, the emphatic declamation of words and stylized acting is the rule. However, there are certain scenes that make the audience identify with the characters of the play, e.g. in Golfo's or Electra's monologue. Moreover, in Orestes and Erofili Synopsis the slow movement of the actors, the music, the lighting effects and the use of masks create a ritual atmosphere.

\section{Greek Theatrical and Popular Tradition}

Horos from 2004 until today tries to explore the roots of the Greek theatre and tradition and promote their continuity through time; touring troupes, shadow theatre, oral tradition, lamentations, folk music and dance, are some elements which characterize a nation (Hatzipantazis, 2006, pp. 117-141). The troupe tours with Golfo and Erofili Synopsis and presents their performance in many towns and villages, drawing inspiration from the Greek "bouloukia" that always used to include Golfo in their repertory. Furthermore, it picks out some of their codes, for example directness with the public, the adaptation of the clown's role who finds ways to attract the audience as well as the simplicity of the scenery, the lack of theatre building with stage and the popular repertory (Kounenaki, 1999). The troupe during its tours communicates with an audience who knows little about theatre, but also collects information about the customs and traditions from specific places (e.g. villages of Crete).

In Goגf $\omega 2.3$ Beta the Greek theatrical tradition emerges through the use of shadow theatre, which is popular in Greece from the 19th century till today (Mystakidou, 1982, pp. 73-77). In the performance, the duel between the two stalwarts, Kitsos and Tasos, is presented with shadow figures, made specifically for the performance in order to represent the characters of the play. The troupe ridicules the scene of the duel using caricatures, teasing and funny beatings, having the intention to express in a humorous way the meaning of bravery and fight, in which the characters take part.

In Erofili-project 2, the troupe brings on stage the Cretan theatrical tradition using Erofili's narration made by the actors and Erotokritos' narration (another popular play of the Cretan theatre of the 17th century, written by Vitsentzos Kornaros) made by the audience, after the performance. The project is based on the roots of the long oral tradition of the play. The narration of the play is followed by a Cretan feast at the small theatre of Epidaurus, where there is traditional local food and drink, dancing and singing, in an effort to create a link with the Cretan popular culture. Another element of it is found in Erofili Synopsis, in Act Five, Scene Three of the play: the actress who plays Erofili, crying and lamenting, while holding Panaretos' dead body, reminds us the Cretan folk lamentations called "moirologia".

In Orestes there is a characteristic example in the First Stasimon of the tragedy, when Chorus narrates Orestes' life. In Kakalas' performance Electra boils Greek coffee in a pot and then serves the two members of Chorus and Orestes. According to the popular belief, you can predict the future by the remains of the Greek coffee from one's cup, this is why the First Stasimon is played by Chorus who tries to predict Orestes' life from his cup. In this humorous way, the director brings to the audience's mind images connected with Greek people's everyday life and at the same time recalls Tsarouchis' paintings with cups of Greek coffee. Actually the performance makes many references to the Greek painter. One of them is in the scene when Pylades leaves with Orestes to go to the political assembly at Argos and then wears a sailor suit and dances the Greek folk dance 
called "zeimbekiko", a solo dance strictly masculine. This dance is Tsarouchis' favorite one and is often depicted on his paintings. Another reference is the scenery, in the first two versions of Orestes, since the scenery includes one of Tsarouchis' paintings showing a sailor drinking Greek coffee. This painting can also be found in the third version of the play. In the last scene of the performance, Kakalas pushes a carriage on which there is a yellow sofa. This sofa comes from Atrides' house and was to be sold in the first version. In this scene of the last version, the troupe sits in this sofa, Tsarouchis' painting is behind and Apollo stands behind the sofa. This synthesis is a finale of reference, honor and remembrance of the Greek painter. But it also refers to "boulouki"- the wandering troupe - that played the performance and now leaves the stage.

\section{Grotesque Presentation of the Characters}

In Kakalas' performances the characters of the play are presented in a grotesque way parodying or copying in an exaggerated form. In the first seven versions of $G o \lambda f \omega$, the leading actress is presented as an innocent foolish girl wearing a school uniform (short skirt, white shirt, long shocks) in blue and white, like the colors of the Greek flag and the leading actor, Tasos, wears a skirt, which reminds the Greek traditional skirt of the Greek soldiers, called "foustanella". In the last gothic version Golfo is dressed in a little black dress with wings and Tasos has long blonde hair and wears a dress coat. A comment on the west way of life is made with the costumes worn by the English Tourists, because they are a kind of a traditional Scottish skirt and a t-shirt showing the English flag.

In Erofili Synopsis, the use of the mask contributes to the exaggeration of the characters, but it is the actors' voice and body which attributes their characteristics; Erofili is presented as a vulnerable girl, Panaretos (his lover) looks, speaks and moves like a good brave man and Filogonos (Erofili's father) is presented as a despot who laughs at others and underestimates them. Their costumes are simple: all the actors are dressed in black. Filogonos is the only one who differentiates because he wears a red cloth as a royal cloak. As Puchner states (1992, pp. 106-108) the play is placed in Baroque and Kakalas tries to create the appropriate atmosphere for his play using in exaggeration the powers of good (Erofili and Panaretos) and evil (Filogonos) in his performance. Moreover, the figure of Haros is presented wearing a bird mask, which reminds us the bird masks of the Renaissance. The actress playing Haros is turned with her back naked and plays with slow movements and a sarcastic voice, creating a scary baroque atmosphere. The soft lighting and the shadings also contribute to this atmosphere.

The parody and the grotesque presentation of the characters in Orestes is an attempt to show the hilarious aspects of the Euripidean play (Dunn, 1996, pp. 158-179). Menelaos' exaggerated and stylized movements express his arrogance which comes from his power. In the Second Episode of the tragedy, his entrance is accompanied by Chorus' applause and cheers. The director's ironic spirit turns against both the king and the mass that welcomes him. Orestes and Menelaos discuss in an unnatural fast rhythm, without looking one another; this is another scenic way of the humiliation of Menelaos and of his fake interest about Orestes' problems. In the same Episode when Orestes and Tyndareo wrangle, the actress (Helena Mavridou) makes the caricature of Tyndareo, the Spartan old man and parodies him, giving him the character of a bloke who comes for a fight and threatens to punish Menelaos in case he helps Orestes. Pylades is presented as a wrathful man who also makes exaggerated and stylized movements as if he were a fitness athlete, prepared to fight. The Messenger (Dimitra Kouza) wears 
an old-fashioned jacket, a long tie and a funny mask bearing the characteristics of a naive villager, who speaks openly without evasions. Frygas is also parodied for his cowardice; he is dressed in oriental costume and traditional slippers and is afraid to walk among dummies on stage. As Polenakis states (2015) parody fits very well with Tsarouchis' translation and style; Kakalas uses it through the whole play in order to subvert it at the end, showing the total decline of the society.

\section{Deduction in Current Issues}

The performances of Horos Theatre Company direct the thought to current issues. The choice of presenting

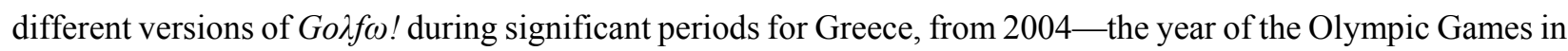
Athens - to 2014 - the period of the economic crisis - is not by chance. Golf $\omega$ ! in the first version of 2004, is a performance with references to the school celebrations of the national anniversaries, engraved in Kakalas' memories since his childhood. The performance is played in a box which opens in front of the audience's eyes and there are Greek flags hanging from the ceiling. The director points out that no matter how much Greek tradition and culture has been altered because of other cultures, they are absolutely connected with the memory of our childhood and our personal experiences (Konstantinakou, 2013).

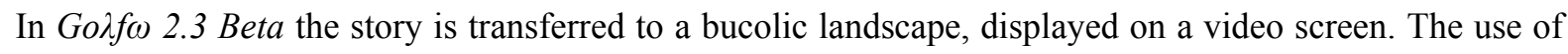
mask helps the actors support the stylized acting and the unnatural mode of speech. During the play, though, by putting off the mask, there have been created psychological perspectives on acting. In Golf $\omega$ ! Director's Cut the slow movement of the actors takes place on a stage which recalls the catwalk and the robotic walking refers to the modern way of life.

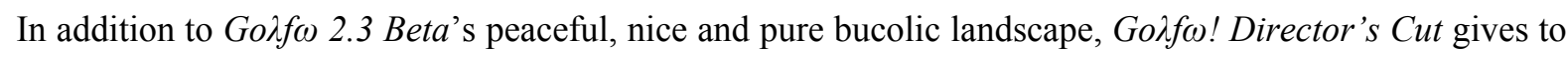
the play a gothic and dim character and depicts the current Greek crisis and the national depression. The space and time of the play shift now into a modern urban environment among pollution and blocks of apartments. On a video screen, images of the city are shown during the performance. Occasionally, the action is stopped by animation which is also displayed on the video screen. Kakalas buries the Greece of the past; he uses a hearse carrying a coffin at the beginning of the performance. At the end of the performance there is not any more salvation because Golfo-Greece is poisoned.

The video screen displays the Greek flag flying worn and tattered, while at the same time the national anthem is heard. The flag-symbol also appears at the beginning of the performance, bloodstained. Golfo is trying to clean it up, but in vain, because the stains are not removed. After the national anthem, the performance ends up with the ERT signal (the signal of the Greek public television) and the old bucolic audio signal, the period during which the public television does not exist anymore in the Greece of crisis. The end of the performance leaves its scar on democracy that no longer exists.

The performance Erofili Synopsis acquires the characteristics of the ritual theatre through the symbolic representation of the scenes of the play of the Renaissance and the stylized movements of the actors accompanied by music. At the end of the play, Erofili's suicide is not shown in a realistic but in a symbolic way; the dead body of Panaretos enlivens and Erofili unites with him both in a death union and in a triumph of love. Puchner states (1992, pp. 88, 108) that Hortatzis play ends with the triumph of love. Erofili Synopsis ends with King Filogonos, standing over the dead couple, and Kakalas" voice is heard saying: "at this point the Chorus of Erofili's girls push 
the King down and lead him to death because of the insult he commits and his arrogance. In this country people today have forgotten to form Chorus that is why, in this performance, the power remains unpunished". Kakalas expresses his sorrow because of the absence of collective efforts and visions, the inaction of people and the lack of political consciousness and awareness in Greece, nowadays.

In Orestes, the troupe wonders what an ancient drama performance can tell to the 21 st century's audience, who is remoted from the ancient Greek myths and the context of the religious festivals of the antiquity. However, in antiquity the presence of citizens in the theatre actually used to be a political action (Goldhill, 1997, pp. 54-69). Euripides' Orestes is a play of political corruption (Euben, 1986, pp. 222-252). Kakalas tries to highlight the political dimension of the play, in Greece and in the world of crisis, where the principles and values have collapsed in a declined democracy.

Euripides' tragedy depicts the problem of restoration of democracy, after its subversion in 411 B.C. by a group of extreme oligarchs, led by Antifontas (Cartledge, 1997, p. 32). Within this environment of decline, the Athenian citizens may find analogies and wonder about the boundaries between democracy and mob rule (Hesk, 2007, p. 82). David Wiles notes (2000, p. 59) that Argos of Euripides' Orestes reminds us an Athens in collapse, where a coup is probable to happen again. When the assembly of Argos has already been completed, the Messenger informs us that there is a man who says that not only is Orestes innocent, but he should wear a wreathe for acting as tyrannicide. Tsarouchis notes (1989a, p. 67) that from a different point of view Orestes is the hero that kills those who are culpable.

In the first post-modern version of Orestes in Avlaia theatre, the action takes place in the living-room of Atreides' family, which is now for sale and Orestes and Electra wait for someone to buy it. This treaty explains the mess of the scenery which is full of objects. The performance is a pastiche of pop culture and modern lifestyle and refers to the young people's lives and the fascistic behavior of rulers. The director's intention is to arise the issue of individual and collective responsibility and to talk about the political practices followed in times of crisis or the anarchy that bursts as a result of it. The focus is given on the interaction with the audience, in research for the role of tragedy in the democratic procedure. Let's not forget that in antiquity, tragedy used to be a means of democracy, since people used to gather altogether at the theatre and tragedy used to be addressed to them and their problems implicitly and ask them to solve them thanks to the collective thought (Cartledge, 1997, pp. 16-22; Hesk, 2007, pp. 72-83; Wiles, 2000, pp. 48-66). Horos tries to redefine the rules and the role of theatre through this performance.

In the second version, the troupe gives emphasis on the deadlock of the two characters and on the rage of the people of Argos. The scenery is simple and looks like a neoclassic bourgeois living-room: it has a yellow sofa, a floor light, a painting of Tsarouchis' and many low tables, which are used by the actors to go up and down during the performance. The whole scene is covered with many dummies, scattered to remind the victims of war, either killed during the fight, sacrificed or murdered. The anger of the people of Argos is expressed on stage at the end of the performance, through the violent outburst of sixty spectators-actors, who run onto the orchestra of the ancient theatre, on the scattered dummies, and start to assault them. This is a direct reference to the anarchy prevailing in times of crisis. The performance ends thanks to the sudden appearance of Apollo as deus ex machina; in the sight of God the sixty actors take pictures with their mobile phones in order to capture the miracle that took place. The humor comes out from Kakalas' ironic spirit because of Apollo's appearance as a TV presenter in a 
reality show, as the director mentions in one of his interviews (Kakalas, 2015). It also comes out from the thought on how much technology has entered into our lives as well as on how many people use their mobiles in every occasion. The fact is that Apollo saves the characters from the disaster. The director's comment is clear: people are unable to solve their problems and wait for a miracle.

The externalization of wrath of the characters and their violent movements as a manifestation of the crisis is presented in the third version as well. The scenery is even more simple; the space is almost empty having only four seats for the actors (two on the left and two on the right), two canvases with long black cloth at the back and many dummies in the centre. These dummies play an important role in this version, because the actors often burst their wrath on them, e.g. when Orestes and Pylades refer to Menelaos or when they want to attack on him at the end of the tragedy, before Apollo appears. In the Prologue, Electra expresses her anger against Helen when she stops talking and starts to beat her repeatedly. Helena Mavridou, the actress playing this role, explains in one of her interviews (Mavridou, 2015) that Electra has accumulated anger and wants to take revenge.

The invocation to the Goddess Nike at the end of the tragedy is not made by Chorus as it is written by Euripides (and as Tsarouchis translates), but Kakalas chooses Apollo to make it without any feeling of sincere devoutness. Apollo requires all the characters to make the sign of the Christian cross, as he does, and he continues the prayer mechanically. The director parodies the religious feeling and at the end of the prayer the actors leave the stage pacing slowly like robots, as if they are marionettes in God's hands.

The end given by Apollo in this tragedy places Orestes neither to the winners nor to the losers; he manages to live and not to be punished by the citizens of Argos but on the other hand, he neither punishes Menelaos, as he planned (Dunn, 1996, pp. 170-173). The comment is clear both from the poet's and the director's side. The tragedy does not have catharsis, the war does not have winners and Helen leaves unpunished. The poet blames the mankind for the suffering brought about by his actions but also his inability to solve his own problems. In Kakalas' performance Apollo sets up this game proving that everything is premeditated to happen. It is people that have the responsibility to get out of the deadlock; the audience understands that in real life there is no Apollo to save them.

\section{Conclusion}

The best way to bring tradition and national identity to the fore is to use a familiar and alive scenic language. Kakalas' performances present his concern on the role of tradition and take a new place in the history of the performances of these "classical" plays. In the last version of Golfo Horos Theatre Company buries Golfo, indicating that national identity is completely erased by capitalism and catholic decline. At the end of Erofili Synopsis, the director concludes with the absence of collective consciousness in modern Greece and in Orestes he ends with the deduction that people remain inactive and wait for a God Apollo to come and save them.

Kakalas notes (2015b) that "nowhere in the world there are pure civilizations; what is 'Greek' is really difficult to say and it is rather complicated". In all versions of the three plays, the director does not defend the Greek culture being against to the foreign ones, nor is he attached to tradition. On the contrary, he renews it combinating attributes of the post-modern and post-dramatic theatre. Moreover, he borrows some features from other cultures (for example he uses gothic elements or manga or Kabuki masks), he makes references to the contemporary, socio-political Greek reality, world theatre (with references to Ariane Mnouchkine or Japanese 
theatre) and uses modern technology (video projections). This modern and innovatory style, however, bears a challenge and constitutes an effective way to make us come in contact with the Greek theatrical history and tradition.

\section{References}

Alexiou, M. (1991). Literature and popular tradition. In D. Holton (Ed.), Literature and society in Renaissance Crete (pp. 239-275). Cambridge: Cambridge University Press.

Beaton, R. (1980). Folk poetry of modern Greece. Cambridge: Cambridge University Press.

Cartledge, P. (1997). Deep plays: Theatre as process in Greek civic life. In P. E. Easterling (Ed.), The Cambridge companion to Greek tragedy (pp. 3-36). Cambridge: Cambridge University Press.

Dunn, F. M. (1996). Tragedy's end: Closure and innovation in Euripidean drama. Oxford: Oxford University Press.

Euben, J. P. (1986). Political corruption in Euripides' Orestes. In J. P. Euben (Ed.), Greek tragedy and political theory (pp. 222-252). California: University of California Press.

Gemert, A. (1991). Literary antecedents. In D. Holton (Ed.), Literature and society in Renaissance Crete (pp. 49-79). Cambridge: Cambridge University Press.

Goldhill, S. (1997). The audience of Athenian tragedy. In P. E. Easterling (Ed.), The Cambridge companion to Greek tragedy (pp. 54-69). Cambridge: Cambridge University Press.

Goward, B. (2004). Telling tragedy: Narrative technique in Aeschylus, Sophocles and Euripides. London: Duckworth.

Gravett, P. (2004). Manga: Sixty years of Japanese comics. London: Laurence King Publishing.

Hall, E. (1993). Political and cosmic turbulence in Euripides' Orestes. In A. Sommerstein et al. (Eds.), Tragedy, Comedy and the Polis. (Papers from the Greek Drama Conference, Nottingham, 18-20 July 1990 (pp. 263-285), Bari).

Hatzipantazis, T. (2006). Greek historic drama. From 19th to 20th century. Irakleio: Panepistimiakes Ekdoseis Kritis.

Hatzipantazis, T. (2010 [ $\left.\left.{ }^{1} 1981\right]\right)$. The comic idyll and its era A. Athens: Ermis.

Hesk, J. (2007). The socio-political dimension of ancient tragedy. In M. McDonald and J. M. Walton (Eds.), The Cambridge companion to Greek and Roman theatre (pp. 72-92). Cambridge: Cambridge University Press.

Ioannides, G. (2010). Erofili-Project 2. Eleftherotypia 21-8-2010. Retrieved from http://www.enet.gr/?i=news.el.article\&id=194812

Kakalas, S. (2010). Simos Kakalas: Interview by N. Hatziantoniou. To Pontiki 26-7-2010. Retrieved from http://www.topontiki.gr/article/8349/simos-kakalas

Kakalas, S. (2015a). Our society is being deceived: Interview by N. Orfanou. Greek Festival 23-7-2015. http:/greekfestival.gr/gr/magazines/article/i-koinonia-mas-paramuthiazetai

Kakalas, S. (2015b). Tragedy is form, rythm, time: Interview by M. Kaltaki. Lifo 31-7-2015. Retrieved from http://www.lifo.gr/team/parastasi/59470

Katsioti, I. (2002). Golfo's luck. In I. Vivilakis (Ed.), Greek theatre from 17th to 20th century. (Papers from the A Hellenic Theatre Conference (pp. 185-207). Faculty of Theatre Studies, University of Athens, Athens: Ergo).

Konstantinakou, P. (2013). From "Made in Greece" to "Made in China": A 21st Century Touring Revival of Golfo, a 19th Century Greek Melodrama. Filmicon Journal, 1(1). Retrieved from http://filmiconjournal.com/journal/article/2013/1/6

Kounenaki, P. (Ed.). (1999). Theatrical bouloukia. Kathimerini, 12 September 1999, 65-126.

Markaki, A. (2015). The politics of marriage and Liebestod in Chortatsis' Erophile. Scandinavian Journal of Byzantine and Modern Greek Studies, (1), 81-111.

Mastronarde, D. J. (2010). The art of Euripides: Dramatic technique and social context. Cambridge: Cambridge University Press.

Mavridou, H. (2016). The interview of the five: Valasoglou, Kakalas, Kouza, Lalos \& Mavridou. Beater 6-3-2015. Retrieved from http://beater.gr/h-sunenteuxh-twn-5-balasogloy-kakalas-lalos/

Mystakidou, A. (1982). Karagöz: Shadow theatre in Greece and Turkey. Athens: Ermis.

Neofytou, T. (2015). Golfo by Peresiadis and the theatrical approaches of Simos Kakalas and of Nikos Karathanos: Nature, light and dark. Parabasis, 13(2), 93-109.

Patsalidis, S. (2004). Post-modern bucolic post-evolutions: Golfo's descendant at N.T.N.G. Aggelioforos tis Kyriakis, 18-4-2004.

Polenakis, L. (2015). Parody is a legitimate style. Avgi 1-9-2015. Retrieved from http://www.avgi.gr/article/5806404/i-parodiaeinai-nomimo-eidos

Puchner, W. (2006). Anthology of modern Greek dramaturgy. From the revolution of 1821 till Asia Minor Catastrophe, B'1. Athens: Morfotiko Idryma Ethnikis Trapezis. 
Puchner, W. (1992). The theatre in Greece: Morphological observations. Athens: Pairidis.

Puchner, W. (1991). Tragedy. In D. Holton (Ed.), Literature and society in Renaissance Crete (pp. 129-159). Cambridge: Cambridge University Press.

Tsarouchis, Y. (Trans.). (1989a). Euripides' Orestes. Athens: Kastaniotis.

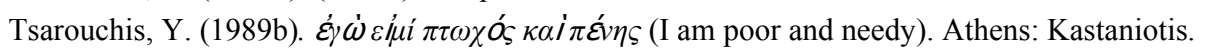

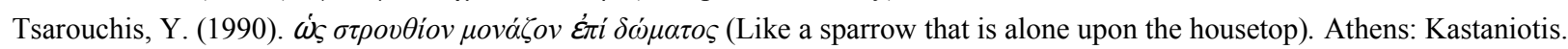
Vasiliou, A. (2004). Modernization or tradition? The prose theatre in Athens in the Interwar period. Athens: Metaichmio.

Wohl, V. (2015). Euripides and the politics of form. Princeton and Oxford: Princeton University Press.

Wiles, D. (2000). Greek theatre performance: An introduction. Cambridge: Cambridge University Press. 